\section{Evaluating Hairy Vetch Residue as Nitrogen Fertilizer for Tomato in Soilless Medium}

\author{
Upendra M. Sainju' ${ }^{1}$, Syed Rahman, and Bharat P. Singh \\ Agricultural Research Station, Fort Valley State University, Fort Valley, \\ GA 31030-3298
}

Additional index words. Vicia villosa, cover crop, Lycopersicon esculentum, fruit production, inorganic nitrogen

\begin{abstract}
The ability of hairy vetch (Vicia villosa Roth) residue (100 g/plant) to supply $\mathbf{N}$ and to increase yields of tomato (Lycopersicon esculentum Mill.) was compared with that of $\mathrm{N}$ fertilization $(0,4.1$, and $8.2 \mathrm{~g}$ /plant $\mathrm{N})$ in a medium containing a mixture of 3 perlite : 1 vermiculite in a greenhouse and a lathhouse. Hairy vetch residue did not interact with $\mathbf{N}$ fertilization in affecting tomato yield and medium $\mathbf{N}$ concentration. In the greenhouse, leaf dry weight, leaf and stem $\mathrm{N}$ uptake, total (fruit + stem + leaf + root) dry weight and $\mathrm{N}$ uptake of tomato, and $\mathrm{NH}_{4}{ }^{+}$and inorganic $\mathrm{N}$ concentrations in the medium at transplanting were significantly greater with than without residue. In the lathhouse, fruit number, fresh and dry yields and $\mathrm{N}$ uptake, leaf, stem, and root dry weights and $\mathrm{N}$ uptake, root length, total dry weight and $\mathrm{N}$ uptake of tomato, and $\mathrm{NH}_{4}^{+}, \mathrm{NO}_{3}^{-}$, and inorganic $\mathrm{N}$ concentrations in the medium at transplanting, and inorganic $\mathrm{N}$ at harvest were greater with than without residue. Nitrogen fertilization increased fruit number, fresh and dry yields and $\mathrm{N}$ uptake, stem, leaf, and root dry weights and $\mathrm{N}$ uptake, root length, and total dry weight and $\mathrm{N}$ uptake. The residue was as effective in increasing fresh fruit yield, total dry weight, and $\mathrm{N}$ uptake as was 4.4 to $7.9 \mathrm{~g} /$ plant of $\mathrm{N}$ fertilizer. Tomato yield and $\mathrm{N}$ uptake per unit amount of $\mathrm{N}$ supplied was greater for the residue than for $\mathrm{N}$ fertilization, suggesting that hairy vetch residue can be effectively used as $\mathbf{N}$ fertilizer for tomato production.
\end{abstract}

Hairy vetch, a legume, fixes $\mathrm{N}$ from the atmosphere. Because of its high $\mathrm{N}$ concentration and low $\mathrm{C}: \mathrm{N}$ ratio, hairy vetch residue (HVR) decomposes rapidly in the soil (Kuo et al., 1997; Stute and Posner, 1995) and supplies a substantial amount of $\mathrm{N}$ to the succeeding crop (Frye et al., 1988; Hargrove, 1986; Kuo et al., 1996, 1997). The residue can supply $50 \%$ to $100 \%$ of the $\mathrm{N}$ requirement of the succeeding crop (McVay et al., 1989), and increased crop yields as much as did 66 to $200 \mathrm{~kg} \cdot \mathrm{ha}^{-1}$ of $\mathrm{N}$ fertilizer (Sainju and Singh, 1997). Cover crops of hairy vetch increased tomato yield (Abdul-Baki and Teasdale, 1993; Abdul-Baki et al., 1996; Sainju et al., 1999). Kelly et al. (1995) found that increased tomato production late in the growing season was greater with hairy vetch than with polyethylene mulch or bare soil, thereby increasing monetary returns even during adverse climatic conditions.

Besides supplying $\mathrm{N}$ and increasing crop production, a cover crop of a hairy vetch can improve soil and water quality by reducing erosion, increasing organic matter, and reducing $\mathrm{NO}_{3}^{-}$leaching to the groundwater (Sainju and Singh, 1997). Nitrogen is released more slowly by HVR than by $\mathrm{N}$ fertilizer and the

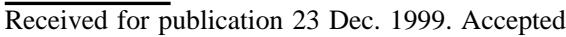
for publication 7 June 2000. The cost of publishing this paper was defrayed in part by the payment of page charges. Under postal regulations, this paper therefore must be hereby marked advertisement solely to indicate this fact.

${ }^{1}$ To whom requests for reprints should be addressed.
} E-mail address: sainjuu@mail.fvsu.edu. release is better synchronized with crop $\mathrm{N}$ demand (Stute and Posner, 1995).

Although HVR increases tomato production, the residue alone may not produce sustainable yields of fresh market fruits; additional $\mathrm{N}$ fertilization may be needed to produce such yields. Since $\mathrm{N}$ is one of the most limiting nutrients for crop production, the interactive effects of HVR and $\mathrm{N}$ fertilization on tomato yield must be evaluated. The concentration of soil $\mathrm{N}$ may also influence the effect of the HVR on tomato production. Therefore, the test must be conducted in a soilless medium devoid of $\mathrm{N}$.

We used a mixture of 3 perlite : 1 vermiculite with or without HVR and $\mathrm{N}$ fertilization for growing tomatoes in a greenhouse. To expose plants to atmospheric conditions as similar to those in the field, we also grew them in the same medium in a lathhouse in the summer. Spaces between laths maintained temperature and moisture levels similar to those outside the house. However, shading reduced the amount of sunlight.

We hypothesized that HVR could supply N and produce tomato yields similar to that produced by $50 \%$ to $100 \%$ of the recommended level of $\mathrm{N}$ fertilization. Our objective was to evaluate the HVR as $\mathrm{N}$ fertilizer for supplying $\mathrm{N}$ and increasing tomato production in a medium containing a mixture of 3 perlite : 1 vermiculite devoid of $\mathrm{N}$.

\section{Materials and Methods}

Treatments. The treatments consisted of two levels of residue (hairy vetch vs. none) and three levels of $\mathrm{N}(0,4.1$, and $8.2 \mathrm{~g} / \mathrm{plant})$. The treatments were arranged in a factorial design with three replications. The amount of HVR (100 g) applied to each pot or tomato plant was based on the equivalent amount of cover crop biomass produced per unit area in the field at the Fort Valley State Univ. farm in Georgia $\left(4 \mathrm{Mg} \cdot \mathrm{ha}^{-1}\right.$ residue $\times 0.25 \mathrm{~m}^{2}$ surface area and $30 \mathrm{~cm}$ depth of the pot). Similarly, the maximum amount of $\mathrm{N}$ fertilization applied to each plant was based on the recommended dose for tomato in central Georgia $\left(180 \mathrm{~kg} \cdot \mathrm{ha}^{-1} \mathrm{~N}\right)$ (Univ. of Georgia, 1995).

Greenhouse. On 10 Feb. 1998, perlite and vermiculite were mixed at a $3: 1$ ratio and $5 \mathrm{~kg}$ of the mixture was transferred to each 19-L polyethylene pot. Field-grown hairy vetch at vegetative stage (103 d after planting) was harvested at $2 \mathrm{~cm}$ above the ground, washed thoroughly with water to remove soil particles, oven-dried at $60^{\circ} \mathrm{C}$ for $3 \mathrm{~d}$, and ground to pass a $1-\mathrm{mm}$ screen. For the residue treatment, hairy vetch ( $\mathrm{N}$ concentration, 30.2 $\pm 1.3 \mathrm{~g} \cdot \mathrm{kg}^{-1}$ ) residue was mixed thoroughly with the perlite and vermiculite at a rate of 100 $\mathrm{g} /$ pot. All pots, with or without residue, were moistened with water, covered with plastic sheets to reduce evaporation, and stored for 2 weeks in the greenhouse to allow $\mathrm{N}$ release from the residue, the perlite and vermiculite mixture, or both before planting tomatoes. The temperature in the greenhouse was maintained at $23{ }^{\circ} \mathrm{C}$ during the day and at $16{ }^{\circ} \mathrm{C}$ during the night during residue incubation and throughout tomato growth.

On 24 Feb. 1998, two 5-week-old tomato (cv. Sunbeam) seedlings were transplanted in the center of the each pot. After 2 weeks, one plant was thinned, leaving only one plant per pot. For the first week after transplanting, $50 \mathrm{~mL}$ of starter solution, containing $3 \mathrm{~g} \cdot \mathrm{L}^{-1}$ each of $\mathrm{N}, \mathrm{P}$, and $\mathrm{K}$, was applied at one time to each plant for rapid establishment. Although this added $0.15 \mathrm{~g} \mathrm{~N}$ to each pot, we assumed that this would not significantly alter the effect of the treatments on growth. Nitrogen fertilizer $\left(\mathrm{NaNO}_{3}, 16 \% \mathrm{~N}\right)$ was applied three times at 3-week intervals after transplanting. The $\mathrm{NaNO}_{3}$ was used because it has a low $\mathrm{N}$ concentration and releases $\mathrm{N}$ more slowly than do $\mathrm{NH}_{4} \mathrm{NO}_{3},\left(\mathrm{NH}_{4}\right)_{2} \mathrm{SO}_{4}$, or urea. Although $\mathrm{Na}^{+}$is toxic to tomato, we found that $\mathrm{Na}^{+}$did not influence tomato growth. All other nutrients were applied in Hoagland's solution using water from the drip irrigation system. Irrigation was turned on for $30 \mathrm{~min}$ with an automatic timer 1 or 2 times a day, depending on the moisture content of the medium. The concentration of the nutrients $\left(\mathrm{mg} \cdot \mathrm{L}^{-1}\right)$ in the solution were: $\mathrm{P}=125, \mathrm{~K}=$ 234, $\mathrm{Ca}=200, \mathrm{Mg}=48, \mathrm{~S}=126, \mathrm{Fe}=5, \mathrm{~B}=$ $0.5, \mathrm{Zn}=0.05, \mathrm{Cu}=0.02$, and $\mathrm{Mo}=0.01$. On 6 Apr. 1998, tomato plants were sprayed with malathion (0,0-dimethyl phosphorodithoate diethyl mercaptosuccinate) at the rate of 6 $\mathrm{g} \cdot \mathrm{L}^{-1}$ to control aphids.

From May to June 1998, fruits were harvested regularly as the color turned from green to pink. Fruits were weighed, cut into slices, oven-dried at $60^{\circ} \mathrm{C}$, weighed again, and ground to pass a 1-mm screen for $\mathrm{N}$ analysis. After all 
fruits were harvested, plants were cut $2 \mathrm{~cm}$ above the surface of the medium, separated into leaves and stems, oven-dried, weighed, and ground. Similarly, roots were separated from the medium, washed thoroughly with water, and stored at $4{ }^{\circ} \mathrm{C}$. After root length was measured, roots were oven-dried, weighed, and ground. Samples of the medium were taken from the surface to the bottom of the pot with a push tube $(2 \mathrm{~cm}$ i.d.) at three places before tomato transplanting and after harvest. Samples were mixed within a pot, air-dried, and ground to pass a 2-mm screen for $\mathrm{N}$ analysis.

Lathhouse. Field-grown hairy vetch (150d after planting) was harvested at $2 \mathrm{~cm}$ above the ground at flowering stage, thoroughly washed with water to remove soil particles, oven-dried at $60{ }^{\circ} \mathrm{C}$ for $3 \mathrm{~d}$, and ground to pass a $1-\mathrm{mm}$ screen. On 17 Apr. 1997, a 5-kg 3 perlite : 1 vermiculite mixture with or without hairy vetch ( $\mathrm{N}$ concentration, $25.5 \pm 1.5 \mathrm{~g} \cdot \mathrm{kg}^{-1}$ ) residue (100 g/pot) was transferred to a $19-\mathrm{L}$ polyethylene pot, moistened with water, and incubated in the lathhouse for 2 weeks. The treatments were arranged in a factorial design with three replications, similar to those in the greenhouse. The average daily temperature in the lathhouse ranged from $11^{\circ} \mathrm{C}$ on $17 \mathrm{Apr}$. to $30{ }^{\circ} \mathrm{C}$ on 3 July 1997 . Total rainfall from 30 Apr. to 31 Aug. 1997 was $544 \mathrm{~mm}$.

On 30 Apr. 1997, two 5-week-old tomato (cv. Sunbeam) seedlings were planted in the center of the each pot. After 2 weeks, one plant was removed, leaving only one plant per pot. As in the greenhouse, starter solution was applied to each plant for the first week, followed by three applications of $\mathrm{N}$ at 3-week intervals; other nutrients were applied in Hoagland's solution with water through the drip irrigation system. On 29 May 1997, chlorothalonil (tetrachloroisophthalonitrile) was applied at $10 \mathrm{~g} \cdot \mathrm{L}^{-1}$ to control leaf molds, caby (mixture of calcium sucrose and sodium borate) was applied at $10 \mathrm{~g} \cdot \mathrm{L}^{-1}$ to control blossom end rot, and endosulfan (hexachlorohexahydromethano-2,4,3-benzodixathiepin-3oxide) was applied at $4 \mathrm{~g} \cdot \mathrm{L}^{-1}$ to control aphids. From July to Aug. 1997, fruit harvest, separation of plants into stems, leaves, and roots, and oven-drying and grinding of the samples for $\mathrm{N}$ analysis were done as in the greenhouse. Similarly, samples of perlite and vermiculite were taken for $\mathrm{N}$ analysis at transplanting and harvest.

Laboratory analysis. The root length of tomato in each pot was determined by using Agvision (Decagon Devices, Pullman, Wash.) The $\mathrm{N}$ concentration in fruits, leaves, stems, and roots was determined by the $\mathrm{H}_{2} \mathrm{SO}_{4}-\mathrm{H}_{2} \mathrm{O}_{2}$ method (Kuo et al., 1997). The $\mathrm{N}$ uptake by fruits, leaves, stems, and roots was determined by multiplying the dry weight by $\mathrm{N}$ concentration, and total $\mathrm{N}$ uptake was determined by adding $\mathrm{N}$ uptake by each of these components. The $\mathrm{NH}_{4}^{+}$and $\mathrm{NO}_{3}^{-}$concentrations in the medium were determined by steam distillation (Mulvaney, 1996). Inorganic $\mathrm{N}$ was determined as the sum of $\mathrm{NH}_{4}{ }^{+}$and $\mathrm{NO}_{3}{ }^{-}$concentrations.

Data analysis. Data for fruit yield, biomass, $\mathrm{N}$ concentration, and $\mathrm{N}$ uptake and $\mathrm{N}$ concentration in the medium were analyzed by using the MIXED procedure of SAS (Littell et al., 1996). Sources of variations were residue treatment, $\mathrm{N}$ fertilization, and their interaction. Means were separated by using the least square means test when treatments and their interactions were significant. Linear regression was used to determine the amount of $\mathrm{N}$ fertilizer required to produce the same effect on tomato yield as HVR. From this analysis, the $\mathrm{N}$ fertilizer equivalence of HVR for the production of each tomato component was determined by extrapolation. Statistical significance was evaluated at $P \leq 0.05$.

\section{Results}

Tomato fruit yield, $N$ concentration, and $N$ uptake. Tomato fruit number, fresh and dry yields, and $\mathrm{N}$ uptake were significantly greater with than without HVR in the lathhouse (Table 1). Fruit number, fresh and dry yields, and $\mathrm{N}$ uptake increased with increasing $\mathrm{N}$ fertilization rate in both the greenhouse and the lathhouse. Fruit fresh and dry yields and N uptake were greater with 8.2 than with 0 and $4.1 \mathrm{~g} / \mathrm{plant} \mathrm{N}$ in the greenhouse, and were greater with 4.1 and 8.2 than with $0 \mathrm{~g} /$ plant $\mathrm{N}$ in the lathhouse. Fruit $\mathrm{N}$ concentration was not influenced by the residue and $\mathrm{N}$ fertilization treatments. Similarly, the interaction of residue and $\mathrm{N}$ fertilization was nonsignificant for fruit number, fresh and dry yields, $\mathrm{N}$ concentration, and $\mathrm{N}$ uptake.

Tomato biomass, $N$ concentration, and $N$ uptake. Tomato stem $\mathrm{N}$ uptake and leaf dry weight and $\mathrm{N}$ uptake were greater with than without HVR in the greenhouse (Table 2). In the lathhouse, stem and leaf dry weights and $\mathrm{N}$ uptake were greater with than without residue. As with the fruits, stem and leaf dry weights and $\mathrm{N}$ uptake increased with increasing rate of $\mathrm{N}$ fertilization, and were greater with 4.1 and 8.2 than with $0 \mathrm{~g} /$ plant $\mathrm{N}$ in the greenhouse and with 8.2 than with $0 \mathrm{~g} / \mathrm{plant} \mathrm{N}$ in the lathhouse. Root length and dry weight were greater with than without residue both in the lathhouse and the greenhouse; in addition $\mathrm{N}$ uptake was greater in the lathhouse (Table 3). Similarly, root length, dry weight, and $\mathrm{N}$ uptake were greater with 8.2 than with $0 \mathrm{~g} /$ plant $\mathrm{N}$ in the lathhouse. Nitrogen concentration of stems, leaves, and roots were not influenced by the treatments (Table 2 and 3). The residue $\times \mathrm{N}$ fertilization interaction was also not significant for stem, leaf, and root dry weights, $\mathrm{N}$ concentration, or $\mathrm{N}$ uptake.

Total (fruit + stem + leaf + root) dry weight and $\mathrm{N}$ uptake were greater with than without residue or $\mathrm{N}$ (Table 2). The root : shoot ratio [root dry weight/(fruit + stem + leaf) dry weight] was not influenced by the treatments in the greenhouse but was lower with than without residue and with 8.2 than with $0 \mathrm{~g} /$ plant $\mathrm{N}$ in the lathhouse (Table 3). Interaction of residue and $\mathrm{N}$ fertilization was nonsignificant for total dry weight, $\mathrm{N}$ uptake, or root : shoot ratio.

Nitrogen concentration in the medium. The $\mathrm{NH}_{4}^{+}$and inorganic $\mathrm{N}$ concentrations in the medium at transplanting were greater with than without HVR in the greenhouse but $\mathrm{N}$ concentration at harvest was not affected (Table 4). In the lathhouse, $\mathrm{NH}_{4}{ }^{+}, \mathrm{NO}_{3}{ }^{-}$and inorganic $\mathrm{N}$ concentrations in the medium at transplanting and inorganic $\mathrm{N}$ at harvest were greater with than without HVR. The $\mathrm{N}$ concentration in the medium at transplanting and harvest was not influenced by $\mathrm{N}$ fertilization in both the greenhouse and lathhouse. Interaction of residue and $\mathrm{N}$ fertilization was also nonsignificant for $\mathrm{N}$ concentration in the medium.

\section{Discussion}

The promotive effect of HVR on tomato fruit number, yield, and $\mathrm{N}$ uptake in the

Table 1 . The effects of hairy vetch residue and $\mathrm{N}$ fertilization on number, fresh and dry yields, $\mathrm{N}$ concentration, and $\mathrm{N}$ uptake of tomato fruits. Plants were grown in a mixture of 3 perlite : 1 vermiculite in the greenhouse and lathhouse.

\begin{tabular}{|c|c|c|c|c|c|}
\hline \multirow[b]{2}{*}{ Treatment } & \multirow[b]{2}{*}{$\begin{array}{l}\text { No. fruit } \\
\text { per plant }\end{array}$} & \multicolumn{2}{|l|}{ Yield } & \multirow[b]{2}{*}{$\begin{array}{c}\mathrm{N} \text { concn } \\
\left(\mathrm{g} \cdot \mathrm{kg}^{-1}\right)\end{array}$} & \multirow[b]{2}{*}{$\begin{array}{c}\text { N uptake } \\
\text { (mg/plant) }\end{array}$} \\
\hline & & \multicolumn{2}{|c|}{${ }_{-}-{ }_{-}(\mathrm{g} / \text { plant })_{-}-{ }_{-}$} & & \\
\hline & & \multicolumn{2}{|l|}{ Greenhouse } & & \\
\hline Residue & & & & & \\
\hline+ & $9.8 \mathrm{a}^{\mathrm{z}}$ & 869 a & $63.2 \mathrm{a}$ & $13.0 \mathrm{a}$ & 817 a \\
\hline- & $8.3 \mathrm{a}$ & 815 a & $58.8 \mathrm{a}$ & $12.2 \mathrm{a}$ & 706 a \\
\hline \multicolumn{6}{|c|}{$\mathrm{N}$ fertilization ( $\mathrm{g} /$ plant) } \\
\hline 0 & $6.3 \mathrm{~b}$ & $501 \mathrm{c}$ & $38.6 \mathrm{c}$ & $11.8 \mathrm{a}$ & $479 \mathrm{c}$ \\
\hline 4.1 & $8.5 \mathrm{~b}$ & $854 \mathrm{~b}$ & $59.9 \mathrm{~b}$ & $12.5 \mathrm{a}$ & $813 \mathrm{~b}$ \\
\hline 8.2 & $12.3 \mathrm{a}$ & $1172 \mathrm{a}$ & $84.4 \mathrm{a}$ & $13.6 \mathrm{a}$ & 992 a \\
\hline Interaction & NS & NS & NS & NS & NS \\
\hline \multicolumn{6}{|c|}{ Lathhouse } \\
\hline \multicolumn{6}{|l|}{ Residue } \\
\hline+ & $9.3 \mathrm{a}$ & $1018 \mathrm{a}$ & $64.3 \mathrm{a}$ & $37.4 \mathrm{a}$ & 2389 a \\
\hline - & $3.7 \mathrm{~b}$ & $496 \mathrm{~b}$ & $31.6 \mathrm{~b}$ & $38.1 \mathrm{a}$ & $1196 \mathrm{~b}$ \\
\hline \multicolumn{6}{|c|}{$\mathrm{N}$ fertilization (g/plant) } \\
\hline 0 & $4.3 \mathrm{~b}$ & $423 \mathrm{~b}$ & $28.1 \mathrm{~b}$ & 38.8 a & $1072 \mathrm{~b}$ \\
\hline 4.1 & $6.3 \mathrm{ab}$ & $865 \mathrm{a}$ & $55.9 \mathrm{a}$ & $36.3 \mathrm{a}$ & 2053 a \\
\hline 8.2 & $8.8 \mathrm{a}$ & 983 a & $59.8 \mathrm{a}$ & $38.1 \mathrm{a}$ & $2252 \mathrm{a}$ \\
\hline Interaction & NS & NS & NS & NS & NS \\
\hline
\end{tabular}

${ }^{\mathrm{z}}$ Mean separation within columns and sets by the least square means test, $P \leq 0.05$.

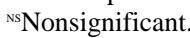


Table 2. The effects of hairy vetch residue and $\mathrm{N}$ fertilization on dry weight, $\mathrm{N}$ concentration, and $\mathrm{N}$ uptake of tomato stems and leaves, and total (fruits + stems + leaves + roots) dry weight and N uptake. Plants were grown in a mixture of 3 perlite : 1 vermiculite in the greenhouse and lathhouse.

\begin{tabular}{|c|c|c|c|c|c|c|c|c|}
\hline \multirow[b]{2}{*}{ Treatment } & \multicolumn{3}{|c|}{ Stems } & \multicolumn{3}{|c|}{ Leaves } & \multicolumn{2}{|c|}{ Total } \\
\hline & $\begin{array}{l}\text { Dry wt } \\
\text { (g/plant) }\end{array}$ & $\begin{array}{l}\mathrm{N} \text { concn } \\
\left(\mathrm{g} \cdot \mathrm{kg}^{-1}\right)\end{array}$ & $\begin{array}{l}\text { N uptake } \\
\text { (mg/plant) }\end{array}$ & $\begin{array}{l}\text { Dry wt } \\
\text { (g/plant) }\end{array}$ & $\begin{array}{l}\text { N conc. } \\
\left(\mathrm{g} \cdot \mathrm{kg}^{-1}\right)\end{array}$ & $\begin{array}{l}\mathrm{N} \text { uptake } \\
\text { (mg/plant) }\end{array}$ & $\begin{array}{l}\text { Dry wt } \\
\text { (g/plant) }\end{array}$ & $\begin{array}{l}\mathrm{N} \text { uptake } \\
\text { (mg/plant) }\end{array}$ \\
\hline \multicolumn{9}{|c|}{ Greenhouse } \\
\hline \multicolumn{9}{|l|}{ Residue } \\
\hline+ & $37.1 \mathrm{a}^{\mathrm{z}}$ & $6.7 \mathrm{a}$ & $247 \mathrm{a}$ & $32.8 \mathrm{a}$ & $11.5 \mathrm{a}$ & 393 a & $135.7 \mathrm{a}$ & $1490 \mathrm{a}$ \\
\hline- & $30.4 \mathrm{a}$ & $6.5 \mathrm{a}$ & $195 \mathrm{~b}$ & $24.8 \mathrm{~b}$ & $11.8 \mathrm{a}$ & $284 \mathrm{~b}$ & $116.2 \mathrm{~b}$ & $1213 \mathrm{~b}$ \\
\hline \multicolumn{9}{|c|}{$\mathrm{N}$ fertilization (g/plant) } \\
\hline 0 & $21.6 \mathrm{c}$ & $6.6 \mathrm{a}$ & $143 \mathrm{c}$ & $17.5 \mathrm{c}$ & $11.6 \mathrm{a}$ & $200 \mathrm{c}$ & $79.5 \mathrm{c}$ & $849 \mathrm{c}$ \\
\hline 4.1 & $34.3 \mathrm{~b}$ & $6.8 \mathrm{a}$ & $228 \mathrm{~b}$ & $28.3 \mathrm{~b}$ & $11.2 \mathrm{a}$ & $313 \mathrm{~b}$ & $125.0 \mathrm{~b}$ & $1385 \mathrm{~b}$ \\
\hline 8.2 & $45.4 \mathrm{a}$ & $6.4 \mathrm{a}$ & $291 \mathrm{a}$ & $40.6 \mathrm{a}$ & $12.2 \mathrm{a}$ & $502 \mathrm{a}$ & $173.4 \mathrm{a}$ & $1823 \mathrm{a}$ \\
\hline Interaction & NS & NS & NS & NS & NS & NS & NS & NS \\
\hline \multicolumn{9}{|c|}{ Lathhouse } \\
\hline \multicolumn{9}{|l|}{ Residue } \\
\hline+ & $26.5 \mathrm{a}$ & $9.1 \mathrm{a}$ & $236 \mathrm{a}$ & $20.5 \mathrm{a}$ & $13.3 \mathrm{a}$ & $285 \mathrm{a}$ & $117.1 \mathrm{a}$ & $3002 \mathrm{a}$ \\
\hline- & $13.2 \mathrm{~b}$ & $9.8 \mathrm{a}$ & $126 \mathrm{~b}$ & $12.0 \mathrm{~b}$ & $13.6 \mathrm{a}$ & $168 \mathrm{~b}$ & $60.9 \mathrm{~b}$ & $1556 \mathrm{~b}$ \\
\hline \multicolumn{9}{|c|}{$\mathrm{N}$ fertilization (g/plant) } \\
\hline 0 & $13.0 \mathrm{~b}$ & $10.1 \mathrm{a}$ & $120 \mathrm{~b}$ & $9.3 \mathrm{c}$ & $12.2 \mathrm{a}$ & $115 \mathrm{~b}$ & $54.3 \mathrm{~b}$ & $1368 \mathrm{~b}$ \\
\hline 4.1 & $19.0 \mathrm{ab}$ & $8.3 \mathrm{a}$ & $160 \mathrm{~b}$ & $16.4 \mathrm{~b}$ & $13.6 \mathrm{a}$ & $227 \mathrm{ab}$ & $96.3 \mathrm{a}$ & $2513 \mathrm{a}$ \\
\hline 8.2 & $27.6 \mathrm{a}$ & $10.1 \mathrm{a}$ & $262 \mathrm{a}$ & $22.9 \mathrm{a}$ & $14.5 \mathrm{a}$ & 337 a & $116.5 \mathrm{a}$ & 2954 a \\
\hline Interaction & NS & NS & NS & NS & NS & NS & NS & NS \\
\hline
\end{tabular}

${ }^{\mathrm{z}}$ Mean separation within columns and sets by the least square means test, $P \leq 0.05$.

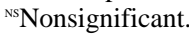

Table 3. The effects of hairy vetch residue and $\mathrm{N}$ fertilization on length, dry weight, $\mathrm{N}$ concentration, and $\mathrm{N}$ uptake of tomato roots, and root : shoot ratio [root dry weight/(fruits + stems + leaves) dry weight)]. Plants were grown in a mixture of 3 perlite : 1 vermiculite in the greenhouse and lathhouse.

\begin{tabular}{|c|c|c|c|c|c|}
\hline \multirow[b]{2}{*}{ Treatment } & \multicolumn{4}{|c|}{ Roots } & \multirow[b]{2}{*}{$\begin{array}{c}\text { Root : shoot } \\
\text { ratio } \\
\end{array}$} \\
\hline & $\begin{array}{l}\text { Length } \\
\text { (m/plant) }\end{array}$ & $\begin{array}{c}\text { Dry wt } \\
\text { (g/plant) }\end{array}$ & $\begin{array}{l}\text { N concn } \\
\left(\mathrm{g} \cdot \mathrm{kg}^{-1}\right)\end{array}$ & $\begin{array}{l}\text { N uptake } \\
\text { (mg/plant) }\end{array}$ & \\
\hline \multicolumn{6}{|c|}{ Greenhouse } \\
\hline \multicolumn{6}{|l|}{ Residue } \\
\hline+ & $350 a^{z}$ & $2.7 \mathrm{a}$ & $12.7 \mathrm{a}$ & $34 \mathrm{a}$ & $0.07 \mathrm{a}$ \\
\hline- & 317 a & $2.3 \mathrm{a}$ & $12.8 \mathrm{a}$ & $28 \mathrm{a}$ & $0.08 \mathrm{a}$ \\
\hline \multicolumn{6}{|c|}{$\mathrm{N}$ fertilization (g/plant) } \\
\hline 0 & $248 \mathrm{~b}$ & $1.9 \mathrm{~b}$ & $14.0 \mathrm{a}$ & $26 \mathrm{a}$ & $0.09 \mathrm{a}$ \\
\hline 4.1 & $365 \mathrm{a}$ & $2.6 \mathrm{a}$ & $11.8 \mathrm{a}$ & $30 \mathrm{a}$ & $0.07 \mathrm{a}$ \\
\hline 8.2 & 389 a & $3.0 \mathrm{a}$ & $12.5 \mathrm{a}$ & $37 \mathrm{a}$ & $0.07 \mathrm{a}$ \\
\hline Interaction & NS & NS & NS & NS & NS \\
\hline \multicolumn{6}{|c|}{ Lathhouse } \\
\hline \multicolumn{6}{|l|}{ Residue } \\
\hline+ & $157 \mathrm{a}$ & $5.8 \mathrm{a}$ & $15.9 \mathrm{a}$ & $92 \mathrm{a}$ & $0.23 \mathrm{~b}$ \\
\hline- & $135 \mathrm{~b}$ & $4.1 \mathrm{~b}$ & $16.2 \mathrm{a}$ & $67 \mathrm{~b}$ & $0.38 \mathrm{a}$ \\
\hline \multicolumn{6}{|c|}{$\mathrm{N}$ fertilization (g/plant) } \\
\hline 0 & $124 \mathrm{~b}$ & $3.9 \mathrm{~b}$ & $16.2 \mathrm{a}$ & $61 \mathrm{~b}$ & $0.38 \mathrm{a}$ \\
\hline 4.1 & $156 \mathrm{a}$ & $4.9 \mathrm{ab}$ & $15.3 \mathrm{a}$ & $74 \mathrm{ab}$ & $0.29 \mathrm{ab}$ \\
\hline 8.2 & $158 \mathrm{a}$ & $6.2 \mathrm{a}$ & $16.7 \mathrm{a}$ & $104 \mathrm{a}$ & $0.24 \mathrm{~b}$ \\
\hline Interaction & NS & NS & NS & NS & NS \\
\hline
\end{tabular}

${ }^{\mathrm{z}}$ Mean separation within columns and sets by the least square means test, $P \leq 0.05$.

${ }^{\mathrm{NS}}$ Nonsignificant.

lathhouse and on stem, leaf, root, and total dry weights and $\mathrm{N}$ uptake in both the greenhouse and lathhouse (Tables 1-3) may have resulted from the greater $\mathrm{N}$ concentration of HVR because $\mathrm{N}$ concentration in the medium at transplanting was also greater with than without residue (Table 4). The greater soil N, tomato fruit yield, biomass, and $\mathrm{N}$ uptake with hairy vetch cover cropping than with bare soil have been reported by several researchers (Abdul-Baki and Teasdale, 1993; Abdul-Baki et al., 1996; Kelly et al., 1995; Sainju et al., 1999, 2000b). Although HVR may have supplied nutrients other than $\mathrm{N}$ and may have affected tomato growth, we assumed that these effects were minimal be- cause $\mathrm{N}$ is the most limiting factor for tomato ass, and $\mathrm{N}$ uptake with than without $\mathrm{N}$ fertiliso may have resulted from incre $\mathrm{N}$ availability (Garton and Widders, 1990; Sainju et al., 1999, 2000a, 2000b; Vavrina et increased $\mathrm{NH}_{4}{ }^{+}$concentration from transplanting to harvest probably resulted from continued $\mathrm{N}$ mineralization from HVR. Nitrogen fertilization, however, did not influence $\mathrm{NH}_{4}{ }^{+}$, $\mathrm{NO}_{3}{ }^{-}$, and inorganic $\mathrm{N}$ concentrations in the medium at transplanting and harvest, probably because $\mathrm{N}$ fertilizer was applied at 3-week intervals after transplanting, and applied $\mathrm{N}$ may have been taken up rapidly by tomato, leached from the pot, or both. The amount of $\mathrm{N}$ leached, however, was not determined.

The reason for the difference in $\mathrm{N}$ concentration in the medium in the greenhouse vs. lathhouse (Table 4) is not known. Although $\mathrm{N}$ concentrations of the HVR used in the greenhouse and lathhouse were similar (30 vs. $25 \mathrm{mg} \cdot \mathrm{kg}^{-1}$ ) and similar amounts of $\mathrm{N}$ fertilizer were used, the greater $\mathrm{N}$ concentration in the medium in the lathhouse (Table 4) also increased fruit, stem, leaf, and root $\mathrm{N}$ concentrations and fruit, root, and total $\mathrm{N}$ uptake (Tables 1-3). The availability of $\mathrm{N}$ can influence tomato $\mathrm{N}$ concentration and uptake (Liptay and Nicholls, 1973; Sainju et al., 2000a, 2000b).

Tomato fruit yield, biomass, and $\mathrm{N}$ uptake increased linearly with increasing rate of $\mathrm{N}$ fertilization in both the greenhouse and the lathhouse (Table 5). Based on the amount of fruit yield, biomass, and $\mathrm{N}$ uptake in the HVR treatment, the $\mathrm{N}$ fertilizer equivalence of the residue ranged from $4.4 \mathrm{~g} / \mathrm{plant} \mathrm{N}$ for fruit fresh and dry yields to $6.2 \mathrm{~g} / \mathrm{plant} \mathrm{N}$ for root dry weight (greenhouse) and from $6.0 \mathrm{~g} /$ plant $\mathrm{N}$ for fruit dry yield to $7.9 \mathrm{~g} / \mathrm{plant} \mathrm{N}$ for fruit fresh yield (lathhouse). Although the $100 \mathrm{~g}$ of residue supplied 2.5 to $3.0 \mathrm{~g} / \mathrm{plant} \mathrm{N}$ (N concentration, 25 to $\left.30 \mathrm{~g} \cdot \mathrm{kg}^{-1}\right)$, the residue was equivalent to 4.4 (greenhouse) and 7.9 (lathhouse), 5.0 (greenhouse) and 7.8 (lathhouse), and 5.3 (greenhouse) and 7.8 (lathhouse) g/plant of $\mathrm{N}$ in its effects upon fruit fresh yield, total plant dry weight, and total $\mathrm{N}$ uptake, respectively (Table 5). The ratio of tomato yield to the amount of $\mathrm{N}$ supplied was 290 (greenhouse) and 407 (lathhouse), 139 (greenhouse) and 211 (lathhouse), and 120 (greenhouse) and 143 (lathhouse) for HVR, $4.1 \mathrm{~g} / \mathrm{plant} \mathrm{N}$, and $8.2 \mathrm{~g} /$ plant $\mathrm{N}$, respectively. This greater yield per unit amount of $\mathrm{N}$ supplied by HVR than by $\mathrm{N}$ fertilization may have resulted from a continuous supply of $\mathrm{N}$ because of $\mathrm{N}$ mineralization from the residue, thereby synchronizing $\mathrm{N}$ release from the residue with tomato $\mathrm{N}$ demand. The HVR decomposes and releases $\mathrm{N}$ more slowly than does $\mathrm{N}$ fertilizer (Hargrove, 1986; Kuo et al., 1997). As a result, $\mathrm{N}$ release by HVR is synchronized with crop N demand (Kuo et al., 1996; Stute and Posner, 1995).

\section{Conclusions}

ratio of increased $\mathrm{N}$ addition from the residue and fertilizer in the lathhouse (Table 3) suggests that tomato shoots grow more rapidly than do roots as $\mathrm{N}$ availability in the medium increases.

The decrease in $\mathrm{NO}_{3}{ }^{-}$concentration in the medium from transplanting to harvest (Table 4) may have resulted from uptake by tomato and/or leaching from the pot. In contrast, 
Table 4. The effects of hairy vetch residue and $\mathrm{N}$ fertilization on $\mathrm{NH}_{4}{ }^{+}, \mathrm{NO}_{3}{ }^{-}$, and inorganic $\mathrm{N}$ concentrations in the 3 perlite : 1 vermiculite mixture at tomato transplanting and harvest.

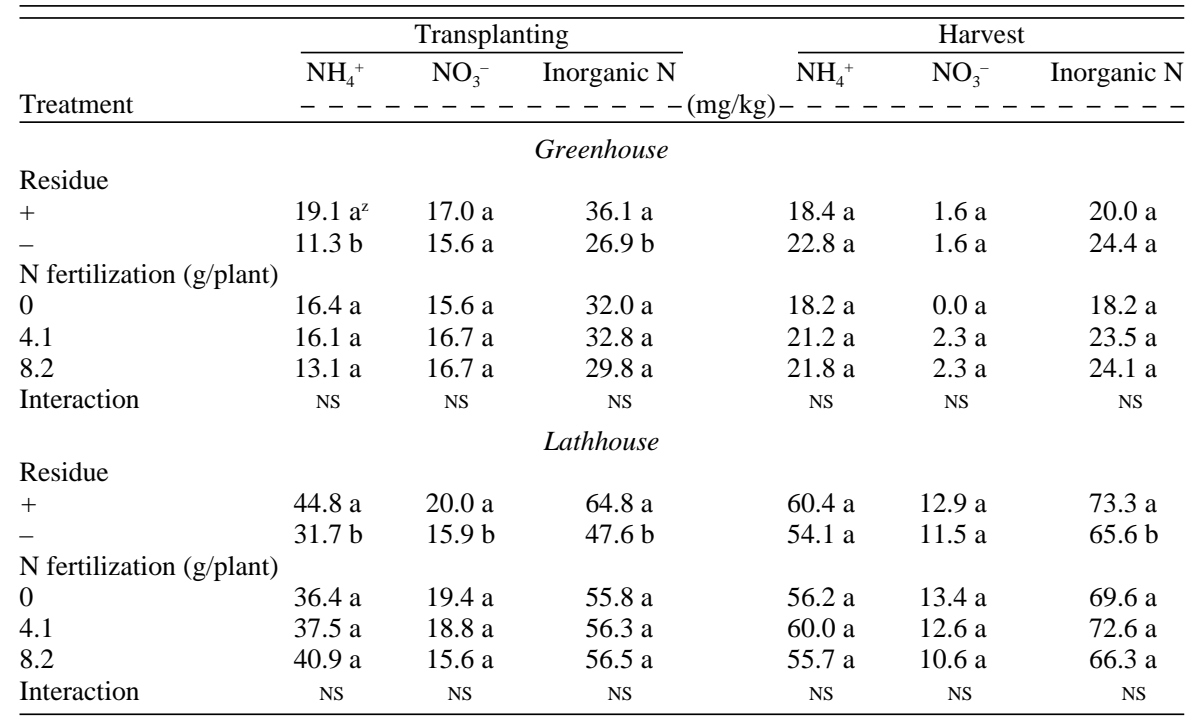

${ }^{\mathrm{z}}$ Mean separation within columns and sets by the least square means test, $P \leq 0.05$.

${ }^{\text {ss }}$ Nonsignificant.

Table 5. Regression analysis of tomato fruit yield, stem, leaf, root, and total (fruits + stems + leaves + roots) dry weight and $\mathrm{N}$ uptake with $\mathrm{N}$ fertilization, and determination of $\mathrm{N}$ fertilizer equivalence (NFE) for hairy vetch residue in the greenhouse and lathhouse $(n=18)$.

\begin{tabular}{|c|c|c|c|c|c|c|c|c|}
\hline \multirow[b]{3}{*}{ Parameter } & \multicolumn{4}{|c|}{ Greenhouse } & \multicolumn{4}{|c|}{ Lathhouse } \\
\hline & $\mathrm{a}$ & $\mathrm{b}$ & $R^{2 \mathrm{z}}$ & $\overline{\mathrm{NFE}}$ & $\mathrm{a}$ & $\mathrm{b}$ & $R^{2 z}$ & NFE \\
\hline & --- & $-(\mathrm{g} / \mathrm{pl}$ & N) - & --- & ---- & - $(\mathrm{g} / \mathrm{pla}$ & v) - & --- \\
\hline Fruit no. & 6.1 & 0.73 & 0.50 & 5.1 & 4.3 & 0.75 & 0.21 & 6.7 \\
\hline Fruit fresh yield & 506.0 & 82.0 & 0.87 & 4.4 & 477.0 & 68.0 & 0.35 & 7.9 \\
\hline Fruit dry yield & 38.3 & 5.6 & 0.86 & 4.4 & 32.1 & 5.4 & 0.29 & 6.0 \\
\hline Fruit $\mathrm{N}$ uptake & 505.0 & 63.0 & 0.77 & 5.0 & 1202.0 & 164.0 & 0.29 & 7.2 \\
\hline Stem dry wt. & 22.0 & 2.9 & 0.68 & 5.2 & 12.6 & 1.8 & 0.31 & 7.7 \\
\hline Stem $\mathrm{N}$ uptake & 145.0 & 18.0 & 0.61 & 5.6 & 110.0 & 17.0 & 0.35 & 7.3 \\
\hline Leaf dry wt. & 17.3 & 2.8 & 0.74 & 5.5 & 9.4 & 1.7 & 0.51 & 6.5 \\
\hline Leaf $\mathrm{N}$ uptake & 188.0 & 37.0 & 0.70 & 5.5 & 115.0 & 27.0 & 0.42 & 6.3 \\
\hline Root length density & 261.0 & 17.0 & 0.35 & 5.2 & 129.0 & 4.0 & 0.28 & 7.0 \\
\hline Root dry wt. & 1.9 & 0.13 & 0.47 & 6.2 & 3.8 & 0.28 & 0.36 & 7.1 \\
\hline Root $\mathrm{N}$ uptake & 26.0 & 1.4 & 0.26 & 5.7 & 58.0 & 5.3 & 0.37 & 6.4 \\
\hline Total dry wt. & 79.0 & 11.4 & 0.87 & 5.0 & 58.0 & 7.6 & 0.36 & 7.8 \\
\hline Total N uptake & 864.0 & 118.0 & 0.79 & 5.3 & 1486.0 & 193.0 & 0.35 & 7.8 \\
\hline
\end{tabular}

${ }^{\mathrm{z}} R^{2}$ values $\leq 0.29$ are significant at $P \leq 0.05$.

to $7.9 \mathrm{~g} /$ plant $\mathrm{N}$ fertilization. As a result, tomato yield and $\mathrm{N}$ uptake per unit amount of $\mathrm{N}$ supplied was greater with HVR than with $\mathrm{N}$ fertilization. Therefore, this residue can be successfully used as $\mathrm{N}$ fertilizer for tomato production.

\section{Literature Cited}

Abdul-Baki, A.A. and J.R. Teasdale. 1993. A notillage tomato production system using hairy vetch and subterranean clover mulches. HortScience 28:106-108.
Abdul-Baki, A.A., J.R. Teasdale, R. Korcak, D.J. Chitwood, and R.N. Huettel. 1996. Fresh-market tomato production in a low-input alternative system using cover crop mulch. HortScience 31:65-69.

Frye, W.W., J.J. Varco, R.L. Blevins, M.S. Smith, and S.J. Corak. 1988. Role of annual legume cover crops in efficient use of water and nitrogen, p. 129-154. In: W.L. Hargrove (ed.). Cropping strategies for efficient use of water and nitrogen. ASA Spec. Publ. 51. Amer. Soc. Agron., Soil Sci. Soc. Amer., Madison, Wis.

Garton, R.W. and I.E. Widders. 1990. Nitrogen and phosphorus preconditioning of small-plug seedlings influences processing tomato productivity. HortScience 25:655-657.

Hargrove, W.L. 1986. Winter legumes as a nitrogen source for no-till grain sorghum. Agron. J. 78:7074.

Kelly, T.C., Y.C. Lu, A.A. Abdul-Baki, and J.R. Teasdale. 1995. Economics of hairy vetch mulch system for producing fresh market tomatoes in the Mid-Atlantic region. J. Amer. Soc. Hort. Sci. 120:854-860.

Kuo, S., U.M. Sainju, and E.J. Jellum. 1996. Winter cover cropping influence on nitrogen mineralization and corn yields. Soil Biol. Fert. 22:310317.

Kuo, S., U.M. Sainju, and E.J. Jellum. 1997. Winter cover cropping influence on nitrogen in soil. Soil Sci. Soc. Amer. J. 61:1392-1399.

Liptay, A. and S. Nicholls. 1993. Nitrogen supply during greenhouse transplant production affects subsequent tomato root growth in the field. J. Amer. Soc. Hort. Sci. 118:339-342.

Littell, R.C., G.A. Milliken, W.W. Stroup, and R.D. Wolfinger. 1996. SAS system for mixed models. SAS Institute, Cary, N.C.

McVay, K.A., D.E. Radcliffe, and W.L. Hargrove. 1989. Winter legume effects on soil properties and nitrogen fertilizer requirements. Soil Sci. Soc. Amer. J. 53:1856-1862.

Mulvaney, R.L. 1996. Nitrogen-Inorganic forms, p. 1123-1184. In: D.L. Sparks, A.L. Page, P.A. Helmke, R.H. Loeppert, P.N. Soltanpour, M.A. Tabatabai, C.T. Johnson, and M.E. Sumner. 1996 (eds.). Methods of soil analysis. Part 3. Chemical methods. Soil Sci. Soc. Amer., Madison, Wis.

Sainju, U.M. and B.P. Singh. 1997. Winter cover crops for sustainable agricultural systems: Influence on soil properties, water quality, and crop yields. HortScience 32:21-28.

Sainju, U.M., B.P. Singh, S. Rahman, and V.R. Reddy. 2000a. Tomato root growth is influenced by tillage, cover cropping, and nitrogen fertilization. HortScience 35:78-82.

Sainju, U.M., B.P. Singh, S. Rahman, and V.R. Reddy. 2000b. Tillage, cover cropping, and nitrogen fertilization influence tomato yield and nitrogen uptake. HortScience 35:217-221.

Sainju, U.M., B.P. Singh, and S. Yaffa. 1999. Tomato yield and soil quality as influenced by tillage, cover cropping, and nitrogen fertilization, p. 104-113. In: J.E. Hook (ed.). Proc. $22^{\text {nd }}$ Annu. Southern Conservation Tillage Conf. for Sustainable Agr., Tifton, Ga. Georgia Agr. Expt. Sta. Spec. Publ. 95. Athens.

Stute, J.K. and J.L. Posner. 1995. Synchrony between legume nitrogen release and corn demand in the upper Midwest. Agron. J. 87:1063-1069.

Univ. of Georgia, 1995. Commercial tomato production and management. Bul. 1116. Coop. Ext. Serv., Univ. of Georgia, Athens.

Vavrina, C.S., G.J. Hochmuth, J.A. Cornell, and S.M. Olson. 1998. Nitrogen fertilization of Florida-grown tomato transplants: Seasonal variation in greenhouse and field performance. HortScience 33:251-254. 